\title{
Nitrous oxide emission from nitrogen fertiliser application in oil palm plantation of different stages
}

\begin{abstract}
The release of nitrous oxide $\left(\mathrm{N}_{2} \mathrm{O}\right)$ from agricultural activities contributes to the increase of greenhouse gases in the atmosphere. In this study, the amount of nitrogen fertiliser used in an oil palm plantation of different stages (immature and mature) was estimated. Data of fertilising scheme at the oil palm plantation for oil palms varying in age (planted between 1986 and 2009) was used. Estimation of nitrous oxide emissions and the resulting $\mathrm{CO}_{2}$ equivalent $\left(\mathrm{CO}_{2}\right.$-eq) emissions were calculated for each category of the oil palm. The amounts of $\mathrm{N}$-fertiliser applied were between $102137 \mathrm{~kg} \mathrm{~N} / \mathrm{ha}$. The resulting $\mathrm{N}_{2} \mathrm{O}$ emissions were between 19.07-22.10 kg N2 $2-\mathrm{O} /$ ha, which corresponds to $\mathrm{CO}_{2}$-eq of between 2223.53$2700.42 \mathrm{~kg} \mathrm{CO}$-eq/ha. It was also estimated that about 29.87-34.63 $\mathrm{g} \mathrm{CO}_{2}$ were emitted per MJ crop. The $\mathrm{N}_{2} \mathrm{O}$ emission per ha oil palm was found to decrease from immature stage until maturely-developed stage spanning 20 years. The $\mathrm{CO}_{2}$-eq amount decreased only after ten years of oil palm development. The results were also compared for synthetic nitrogen fertiliser-induced emissions within tropical regions.
\end{abstract}

Keyword: Nitrous oxide; N2O emissions; CO2 equivalent; Greenhouse gases; GHG emissions; Global warming; Oil palm plantations; Nitrogen fertilisers; Agriculture 